\title{
«Zouav-bataljons-amputør N.N》 og legenes kamp mot kvakksalveriet
}

Norge fikk sin første kvakksalverlov i 1794, den såkalte kvakksalverforordningen. Den hadde imidlertid varierende effekt, og en rekke kjente kvakksalvere befolket landsbygda i Norge gjennom hele 1800-tallet og nøt til dels stor anseelse. Man kunne ifølge forordningen av 1794 søke godkjennelse for å behandle visse sykdommer. I 1871 ble kvakksalverforordningen revidert og gjort noe mer liberal. I 1888 sendte Legeforeningen ut et spørreskjema til alle landets leger for å kartlegge «uvesenets» omfang. Men det var få som svarte, så derfor kom det ikke noe utspill til myndigheten. Da sunnhetskommisjonen i Kristiania foreslo at også kvakksalvere skulle pålegges å innrapportere til myndighetene de venerisk syke de hadde under behandling, vakte det imidlertid sterke reaksjoner. Profesjonens integritet var truet. Under følger redaksjonens meningsytring i den anledning (Tidsskrift for praktisk Medicin 1888; 8: 146-7):

Kvaksalveres anmeldelsespligt. Kristiania sundhedskommission har foreslaaet, at kvaksalvere skal paalægges at indmelde de tilfælde av veneriske sygdomme, som kommer under deres behandling, ligesom lægerne. Forslaget er vedtaget af formandskabet, men blev i represæntantskabet udsat, for at det medicinske selskabs betænkning kunde indhentes i sagen. Vi føler os overbevist om, at selskabet ikke vil kunne tilraade et paa den ene side saa unyttigt, paa den anden side skadelig skridt. Det er nemlig paa forhaand klart, at man ikke fra hr. Zouav-bataljons-amputør N.N. eller hr. «hygieniker» M.M vil kunne faa oplysninger af nogensomhelst værdi for den officielle statistik. D'hrr. kan ikke med nogensomhelst sikkerhed stille en diagnose og ved det selv. Endmindre vil man hos denne stand, hvis hele haandtering er et mere eller mindre bevidst bedrag, kunne vente nogen interesse for den offentlige sundhedspleie, end sige oplysninger om smittekilder, som kunde paadrage dem i hvert fald bryderi, muligens ogsaa en nærgaaende og for deres virksomhed skadelig kritik. Under disse omstændigheder maa vi indstændigt fraraade, at kommunen indlader sig i nogensomhelst forretnings-forbindelse med mænd, hvis hele virksomhed strengt maa fordømmes. Men navnlig fordi det kan blive en hindring for den reform, som den nuværende situation og den offentlige sundhedspleie alvorligt kræver: at ret til at behandle smitsomme sygdomme forbeholdes dem, som ved studium og eksamen har lagt for dagen, at de dertil er skikkede. 